\title{
Designing an expert system for determining student learning styles using forward chaining in engineering education
}

\author{
Muhammad Anwar ${ }^{*}$ \\ Universitas Negeri Padang, Indonesia
}

\author{
Article Info \\ Article history: \\ Received Jan $12^{\text {th }}, 2021$ \\ Revised Feb $06^{\text {th }}, 2021$ \\ Accepted Feb $22^{\text {nd }}, 2021$
}

\section{Keyword:}

Learning style

Expert system

Forward chaining

Engineering education

\begin{abstract}
Engineering education prepares its graduates able to work in the community and entrepreneurship, the quality of graduates is highly determined by the quality of the learning process is no exception for student learning styles. The purpose of this study was to describe the design of the expert system to determine the student learning style, the method used was forward chaining. The results of the design of this application have been able to diagnose student learning styles efficiently and provide the best solutions for their learning.
\end{abstract}

C 2021The Authors. Published by Indonesian Institute for Counseling,

Education and Therapy (IICET). This is an open access article under the CC BY license (https://creativecommons.org/licenses/by/4.0/)

\author{
Corresponding Author: \\ Muhammad Anwar, \\ Universitas Negeri Padang \\ Email:muh_anwar@ft.unp.ac.id
}

\section{Introduction}

Engineering education is an education that prepares graduates to be prepared and able to work in the world of work (Ganefri et al., 2017; Tasrif, 2019; Anwar, 2021). Not only ready to work but with the competence possessed by a graduate of engineering education, required to be able to open employment (Hidayat et al, 2019a, 2019b, 2019c; Hidayat et al., 2020), and entrepreneurship (Ganefri et al., 2018; Hidayat, 2017a, 2017b; Hidayat, \& Yuliana, 2018; Hidayat et al., 2018a, 2018b). The challenges of global competition and the digital era demanding higher education more seriously to prepare graduates of engineering education (Tasrif et al., 2021). Preparedness and quality graduates are highly determined by the learning process (Anwar, 2019), Learning Model (Hidayat, 2015; Aryanti, Anwar, \& Zulwisli, 2017; Andrianis, Anwar, \& Zulwisli, 2018), and management quality management (Tasrif, 2019). Learning is a process of change in the human personality and these changes are dumped in the form of improving the quality and quantity of behavior such as increasing knowledge, emotional increase, behavior and habit (Pane, 2017; Tasrif et al., 2020). Learning is not just to study general science, but with learning, individual behavior is better (Sari, 2014; Pane, 2017). Individuals who experience a learning process will get a change in which he also did not know to know that it formed a quality human being (Sari, 2014).

The teaching and learning process that occurs is like a flashlight that is reflected in the wall (sari, 2014). In the learning process should be the speed of the student brain capturing information from the teacher is $1,287 \mathrm{~km} \mathrm{/} \mathrm{h}$ the same as the speed of light coming out of the flashlight. If the statement is correct, why is there still many failures in the learning process. Previous research states that there are many factors that influence student failure in learning, one of which is learning style. We all have a learning style, the same unique thinking style with our fingerprints. We each receive information, save knowledge and retrieve it again in different ways. The statement explains that every individual is born with its own uniqueness which they have differences in each other. Like physical differences, mindset, how to respond and remember new 
things. No exception for students, they have their own way of compiling what has just been learned to be remembered by the brain.

Learning styles are interpreted as individual preferences who are rooted for the type of learning in each individual (Vorhaus, 2010; Felder et al., 2000). For example, how to fold your hands. Every individual has each way to fold your hands. Likewise with theory and style of learning, there is someone who prefers to learn something with pictures and diagrams and some who prefer the words (Vorhaus, 2010), is no exception also in engineering education. The learning style in technical education certainly has a particular uniqueness and characteristics (Felder, \& Silverman, 1988).

Artificial intelligence is defined as a machine that is able to think, weigh the actions to be taken, and able to make decisions such as those carried out by humans (Akil, 2017; Harjanto, Karnila, and Nugraha, 2018). Intelligence is inserted into the computer in order to do work as a human can do. Some areas that use artificial intelligence include expert systems, computer games (games), fuzzy logic, artificial neural networks, and robotics. An expert system is a system that is able to imitate the reasoning of an expert so that computers can solve problems as usual by experts (Sari, 2013; Waliyansyah, Novita, and Aditasar, 2020). The important role of an expert can be replaced by a computer program which is on the principle of work to provide a sure solution as usual by experts. Expert systems are usually used for consulting, analysis, diagnosis, and help make decisions.

Determination of learning styles with certain methods and methods have been carried out in previous studies and provide good results, such as predictions of learning styles with Fuzzy Decision Trees (Kanninen, 2009; Hsu, Wang, \& Huang, 2010; Latham et al., 2012; Ghadirli, \& Rastgarpour, 2013; Crockett, Latham, \& Whitton, 2017), one of which is by the forward chaining method. The forward chaining method is an inference multiplication that connects a problem with a solution called the chain (Harjanto et al., 2018). Chains that are passed or crossed from a problem to obtain a solution are called forward chaining. The Forward Chaining method is one of the two main methods of reasoning (thought) when using an inference engine (decision maker) and can be logically described as a repetition application (a set of rules of inference and valid arguments). Based on the problems and information proposed a solution that can be used to determine the student learning style, an expert system application that has the ability to analyze the type of student learning style. The application of this expert system can help students find the best solution or learning method for the students. For teachers, the results of the detection of learning styles can also help in selecting the right methods or learning strategies. Thus, the process and learning outcomes of students can be more optimal.

\section{Method}

This expert system will solve a problem in the expert system which in this design is carried out using forward chaining techniques which are troubleshooting from the facts to a conclusion. That is, tracking starts from the state of the facts and then matches with the expected goal. The application of inference machines with the logic of IF-THEN rules with the forward chaining method is seen as follows.

Rule 1 : IF (G01 AND G02 AND G03 AND G04 AND G05 AND G06 AND G07 AND G08 AND G09) THEN H01

Rule 2 : IF (G01 AND G02 AND G03 AND G04 AND G10 AND G11 G12 AND G13 AND G14 AND G15) THEN H02

Rule 3 : IF (G16 AND G17 AND G18 AND G19 AND G20 AND G21 AND G22 AND G23 AND G24 AND G25 AND G26 AND G27) THEN H03

Rule 4 : IF (G16 AND G17 AND G18 AND G19 AND G20

AND G21 AND G28 AND G29 G30 AND G31 AND G32) THEN H04

Rule 5 : IF (G33 AND G34 AND G35 AND G36 AND G37 AND G38 AND G39 G40 AND G41 AND G42) THEN H05

Rule 6 : IF (G33 AND G34 AND G35 AND G36 AND G37

AND G38 AND G43 AND G44 AND G45 AND 46) THEN H06

Rule 7 : IF (G47 AND G48 AND G49 AND G50 AND G51 AND G52) THEN H07 
Activity diagrams describe the process and sequence of activity in an expert system process. The activity diagram describes the event when the user accesses the home menu, as seen in the following image.

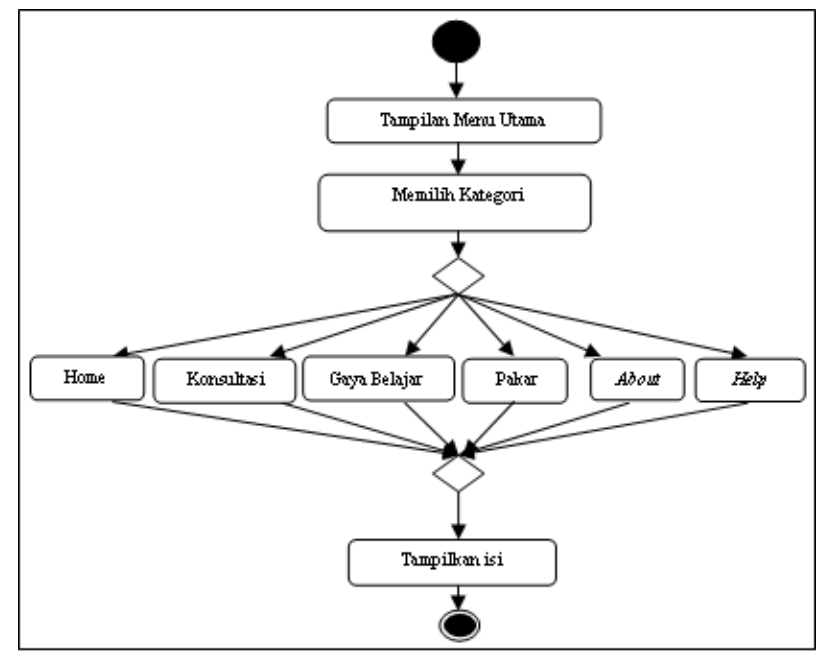

Figure 1. Activity Expert System Diagram

\section{Decision Tree}

To determine the flow of the question and decisions of the expert system, a decision tree or decision tree that contains the flow of questions about learning styles. The following is a decision tree for learning style in the expert system that will be designed.

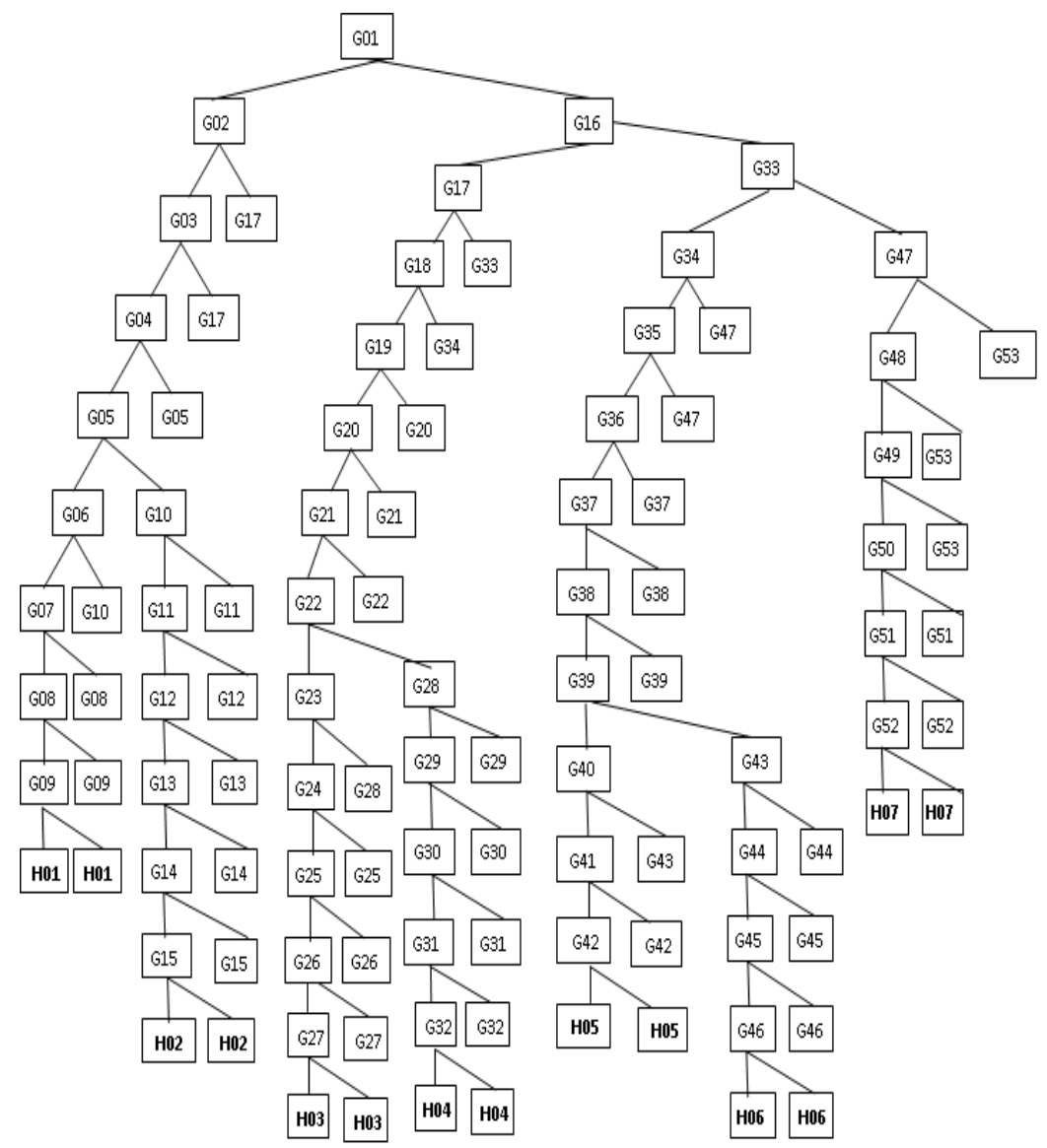

Figure 2. Decision Tree Expert System 


\section{Results and Discussion}

Research related to the learning style has been done a lot before (Balasubramaniam, \& Indhu, 2016; Stirling, \& Alquraini, 2017; Alkooheji, \& al-Hattami, 2018). Learning style for certain expertise and material, such as the ability to write (Untoro, 2016), the ability to draw (Rais, Aryani, \& Ahmar, 2018), also affecting attitude learning (Weng et al., 2018), has an impact on Blended Learning (Shamsuddin , \& Kaur, 2020), there is also a relationship between learning styles with teaching style (Toyama, \& Yamazaki, 2020), the impact on the Working Group (Soetanto, \& Macdonald, 2017), the combination of cooperative learning and learning styles of conceptual understanding (Kade, DeGeng, \& Ali, 2019), and Student's Higher Order Thinking Skill Level (Zulfiani, SuWarna, \& Sumantri, 2020). Furthermore, this learning style can also be identified through the algorithm and expert system (Bernard et al., 2017), through simulation (Çelik, Ceylantekin, \& KiliIc, 2017), using Learning Analytics (Jena, 2018), through game games (Khamparia, \& Pandey, 2018). However, learning styles also need to be evaluated (Ibrahim, \& Hussein, 2016; O'mahony et al., 2016).

Engineering education in the learning process also certainly has the uniqueness of learning style (LarkinHein, \& Budny, 2001). This learning style can be predicted with a specific application design through the Expert System (Movafegh Ghadirli, \& Rastgarpour, 2013; Márquez et al., 2015; Ozdemir et al., 2016; Marlinda, Saputra, \& Indrarti, 2019; Sakaan, \& abdel-wahab, 2021), one of them is by the forward chaining method. The system discussion is the implementation of a process that translates the design results into the form of software in full (Ekayani, 2017). The implementation of the interface is to translate layouts that have been made on the interface design into the form of a system of intact interfaces (Sidharta and Wati, 2015). The implementation of the system interface is done to find out whether the system that has been designed can run correctly according to the design that has been previously designed.

\section{Main Page}

The main menu display is a menu that will appear when the program is executed after going through the boot process. The following is the result of the consultation menu display on this application.

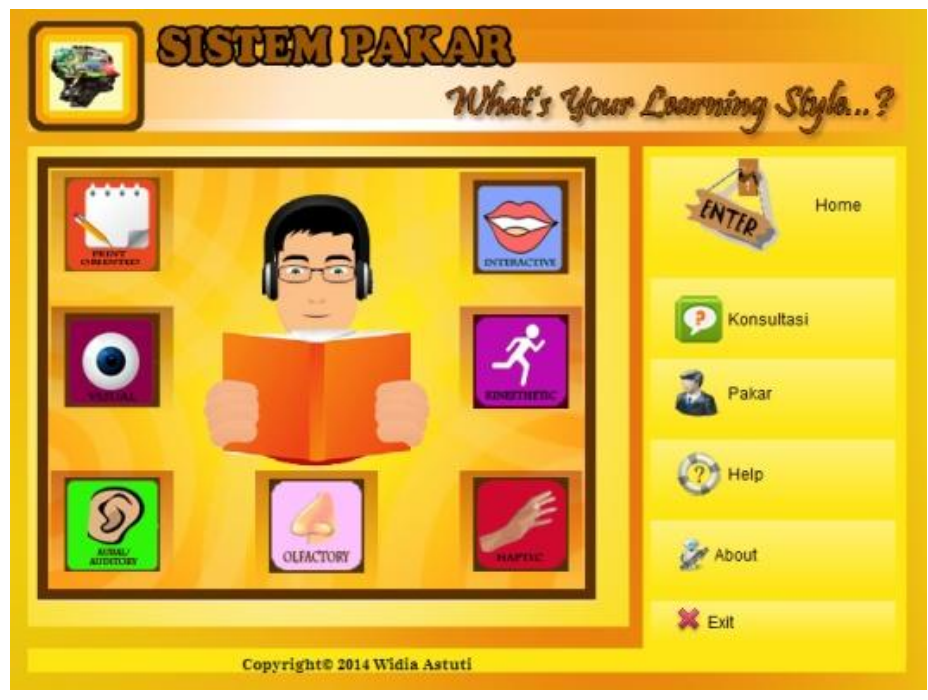

Figure 3. Display the main menu

\section{Consulting Menu}

The consultation menu display will appear when the user selects Button consultation on the main menu. The consultation menu will ask questions to the user and provide the "yes" and "no" answer options. At the end of the consultation, the system will provide a diagnosis in the form of a type of learning force equipped with information on what Button, why, and how. But if the system does not find a user learning style, the system will bring a user to a complaint menu so that the user can share the problem with experts. 


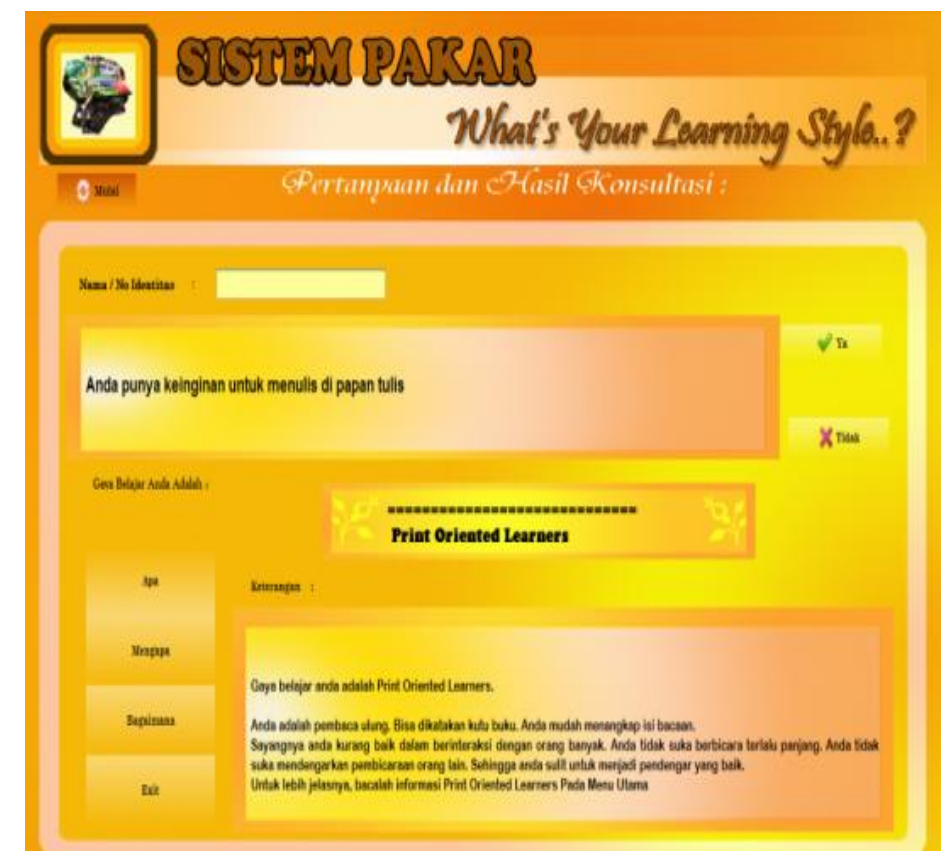

Figure 4. Display the Consultation Menu

\section{Complaint Menu}

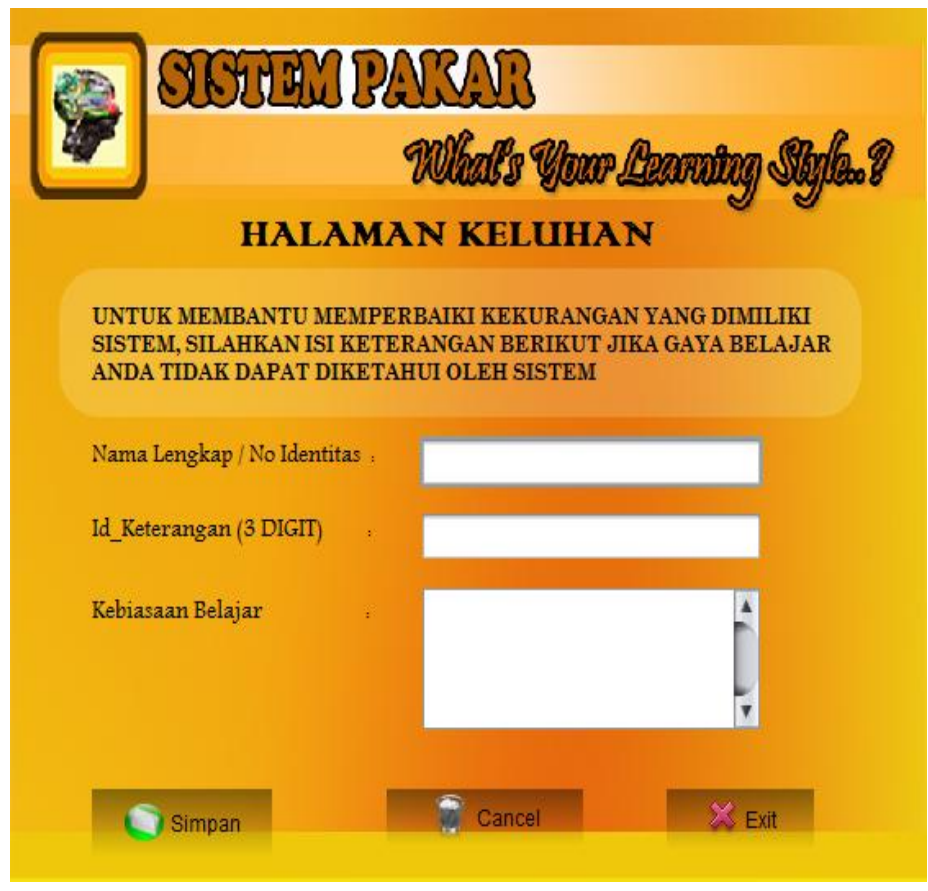

Figure 5. Look Page Complaint 


\section{Main Information Menu}

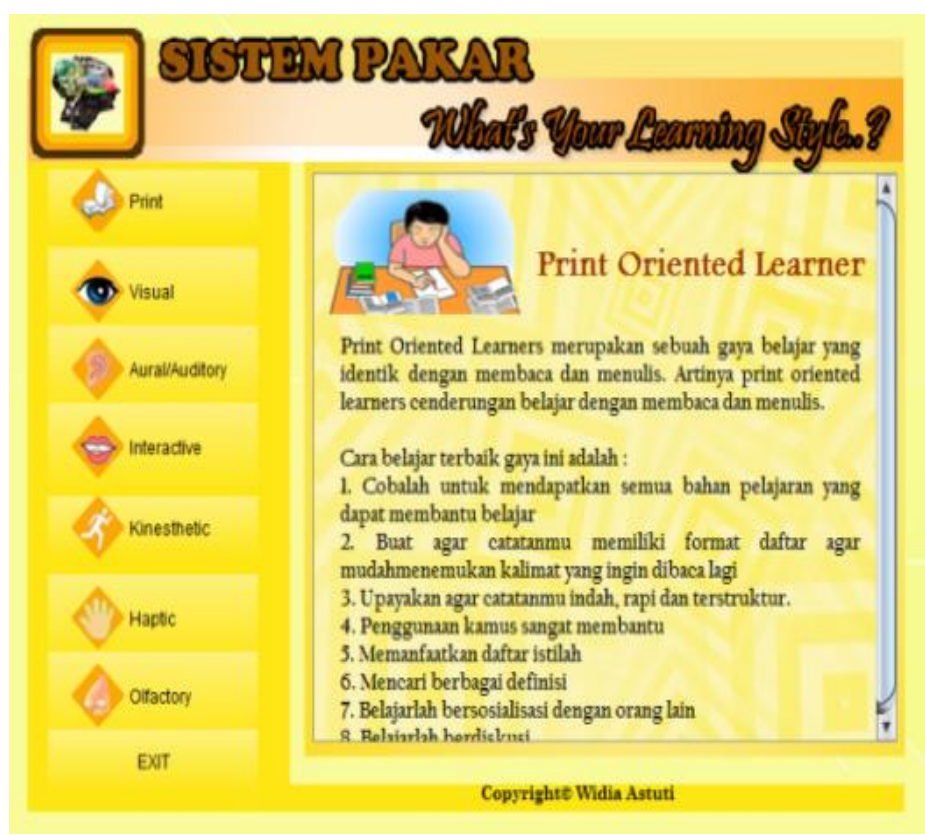

Figure 6. Display Information Menu

\section{Expert Menu}

The expert menu that functions as a system repair media. Among them, there are menus that create new accounts, style data, knowledge data, candidate data, expert data, and explanatory data.

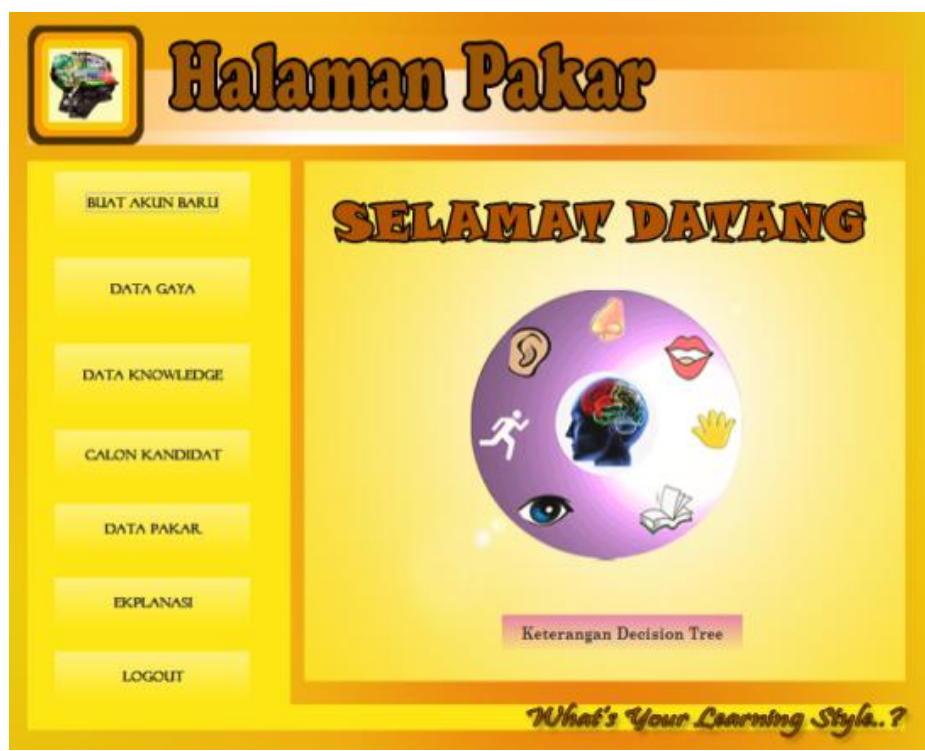

Figure 7. Expert Menu Display

\section{Conclusion}

Conclusions that can be taken from the design of the expert system to determine the type of student learning style is the application of this expert system already able to diagnose the type of student learning style and find the best learning method for students. This application can be used by students as the main user and parents of students or teachers who want to know the student learning style. Teachers or experts who have knowledge of learning styles can be experts to make improvements to this system. 


\section{References}

Akil, Ibnu. (2017). Analisa Efektifitas Metode Forward Chaining Dan. Jurnal Pilar Nusa Mandiri, 13(1), 3542.

Alkooheji, L., \& Al-Hattami, A. (2018). Learning Style Preferences among College Students. International Education Studies, 11(10), 50-63.

Andrianis, R., Anwar, M., \& Zulwisli, Z. (2018). Pengaruh Model Pembelajaran Berbasis Projek Terhadap Hasil Belajar Pemrograman Web Dinamis Kelas Xi Rekayasa Perangkat Lunak Di Smk Negeri 2 Padang Panjang. VoteTEKNIKA: Jurnal Vocational Teknik Elektronika dan Informatika, 6(1).

Anwar, M. (2019). Kontribusi Self Efficacy Dan Self Regulated Terhadap Kesiapan Kerja Siswa Kelas Xii Teknik Audio Vidio Smk N 1 Padang. Jurnal Kapita Selekta Geografi, 2(10), 1-15.

Anwar, M. (2021). Problem Solving Skills Analysis of Vocational Engineering Teacher Candidates in Term of Several Variables. Journal of Education Technology, 5(1). doi:http://dx.doi.org/10.23887/jet.v5i1.33624

Aryanti, L., Anwar, M., \& Zulwisli, Z. (2017). Pengaruh Penerapan Model Pembelajaran Inkuiri Terhadap Hasil Belajar Teknik Elektronika Dasar Siswa Kelas X SMKN 5 Padang. VoteTEKNIKA: Jurnal Vocational Teknik Elektronika dan Informatika, 5(2).

Balasubramaniam, G., \& Indhu, K. (2016). A study of learning style preferences among first year undergraduate medical students using VARK model. Education in Medicine Journal, 8(4).

Bernard, J., Chang, T. W., Popescu, E., \& Graf, S. (2017). Learning style Identifier: Improving the precision of learning style identification through computational intelligence algorithms. Expert Systems with Applications, 75, 94-108.

Çelik, Y., Ceylantekin, Y., \& Kiliç, İ. (2017). The evaluation of simulation market in nursing education and the determination of learning style of students. International journal of health sciences, 11(1), 1.

Crockett, K., Latham, A., \& Whitton, N. (2017). On predicting learning styles in conversational intelligent tutoring systems using fuzzy decision trees. International Journal of Human-Computer Studies, 97, 98-115.

Ekayani, P. (2017). Pentingnya penggunaan media pembelajaran untuk meningkatkan prestasi belajar siswa. Jurnal Fakultas Ilmu Pendidikan Universitas Pendidikan Ganesha Singaraja, 2(1), 1-11.

Felder, R. M., \& Soloman, B. A. (2000). Learning styles and strategies.

Ganefri, Hidayat, H., Kusumaningrum, I., \& Mardin, A. (2017). Needs Analysis of Entrepreneurship Pedagogy of Technology and Vocational Education with Production Based Learning Approach in Higher Education. International Journal of Advanced Science, Engineering and Information Technology, 7, 1701-1707. http://dx.doi.org/10.18517/ijaseit.7.5.1510

Ganefri, G., Hidayat, H., Yulastri, A., Mardin, A., Sriwahyuni, D., \& Zoni, A. A. (2018). Perangkat Pembelajaran Pedagogi Entrepreneurship Dengan Pendekatan Pembelajaran Berbasis Produk di Pendidikan Vokasi. In Prosiding Seminar Nasional \& Internasional, 1(1).

Ghadirli, H. M., \& Rastgarpour, M. (2013). A Model for an Intelligent and Adaptive Tutor based on Web by Jackson's Learning Styles Profiler and Expert Systems. arXiv preprint arXiv:1304.4045.

Harjanto, Arif, Sri Karnila, and Fajar Nugraha. (2018). Rancang Bangun Aplikasi Sistem Pakar Untuk Konsultasi Perilaku Siswa Di Sekolah Menggunakan Metode Forward Chaining. Simetris: Jurnal Teknik Mesin, Elektro Dan Ilmu Komputer, 9(2), 817-24.

Hidayat, H. (2015). Production based Learning: An Instructional Design Model in the context of vocational education and training (VET). Procedia-Social and Behavioral Sciences, 204, 206-211.

Hidayat, H. (2017a). How is the Application and Design of a Product-Based Entrepreneurship Learning Tools in Vocational Higher Education?. In International Conference on Technology and Vocational Teachers (ICTVT 2017) (pp. 223-228). Atlantis Press.

Hidayat, H. (2017b). Impact of learning with the production-based learning model in vocational school. International Journal of Research in Engineering and Social Sciences, 7(2), 1-6.

Hidayat, H., Herawati, S., Tamin, B. Y., \& Syahmaidi, E. (2018a). How is the practicality of technopreneurship Scientific learning model design in vocational higher education?. International Journal of Scientific Research and Management, 6(09).

Hidayat, H., Herawati, S., Syahmaidi, E., Hidayati, A., \& Ardi, Z. (2018b). Designing of technopreneurship scientific learning framework in vocational-based higher education in Indonesia. International Journal of Engineering and Technology (UAE), 7(4), 123-127.

Hidayat, H., \& Yuliana. (2018). The Influence of Entrepreneurship Education and Family Background on Students' Entrepreneurial Interest in Nutritious Traditional Food Start Ups in Indonesia. International Journal of Engineering and Technology(UAE). 7(4), 118-122. https://doi.org/10.14419/ijet.v7i4.9.20631 
Hidayat, H., Tamin, B. Y., Herawati, S., Khairul, K., \& Syahmaidi, E. (2019a). The contribution of technopreneurship scientific learning and learning readiness towards the entrepreneurship learning outcomes in higher vocational education. Jurnal Pendidikan Vokasi, 9(1), 21-32.

Hidayat, H., Ardi, Z., Yuliana, \& Herawati, S. (2019b). Exploration of the need analysis for technopreneurship scientific learning models in higher vocational education. International Journal of Economics and Business Research, 18(3), 356-368.

Hidayat, H., Tamin, B.Y., Herawati, S., Hidayati, A., Muji, A.P. (2019c). Implementation of technopreneurship scientific learning for produce electronic product prototypes in engineering education. International Journal of Innovative Technology and Exploring Engineering, 8(11), 28422846. http://dx.doi.org/10.35940/ijitee.K2406.0981119

Hidayat, H., Tamin, B. Y., Herawati, S., Ardi, Z., \& Muji, A. P. (2020). The Contribution of Internal Locus of Control and Self-Concept to Career Maturity in Engineering Education. Int. J. Adv. Sci. Eng. Inf. Technol, 10(6), 2282-2289.

Hsu, C. C., Wang, K. T., \& Huang, Y. M. (2010). Modeling personalized learning styles in a web-based learning system. In Transactions on edutainment IV (pp. 12-21). Springer, Berlin, Heidelberg.

Ibrahim, R. H., \& Hussein, D. A. (2016). Assessment of visual, auditory, and kinesthetic learning style among undergraduate nursing students. Int J Adv Nurs Stud, 5(1), 1-4.

Jena, R. K. (2018). Predicting students' learning style using learning analytics: a case study of business management students from India. Behaviour \& Information Technology, 37(10-11), 978-992.

Kade, A., Degeng, I., \& Ali, M. (2019). Effect of jigsaw strategy and learning style to conceptual understanding on senior high school students. International Journal of Emerging Technologies in Learning (iJET), 14(19), 4-15.

Kanninen, E. (2009). Learning styles and e-learning. Tampere: Tampere University of Technology, 1, 5-29.

Khamparia, A., \& Pandey, B. (2018). Effects of visual map embedded approach on students learning performance using Briggs-Myers learning style in word puzzle gaming course. Computers \& Electrical Engineering, 66, 531-540.

Larkin-Hein, T., \& Budny, D. D. (2001). Research on learning style: Applications in the physics and engineering classrooms. IEEE Transactions on Education, 44(3), 276-281.

Latham, A., Crockett, K., McLean, D., \& Edmonds, B. (2012). A conversational intelligent tutoring system to automatically predict learning styles. Computers \& Education, 59(1), 95-109.

Marlinda, L., Saputra, D., \& Indrarti, W. (2019). Expert System Identification Of Learning Patterns The VARK Method. Sinkron: Jurnal dan Penelitian Teknik Informatika, 3(2), 205-211.

Márquez, I. N., Rodríguez, L. F., Lugo, G. S., Castro, L. A., \& Kono, M. D. (2015). A Framework for Automatic Identification of Learning Styles in Learning Management Systems. Res. Comput. Sci., 106, 59-68.

Movafegh Ghadirli, H., \& Rastgarpour, M. (2013). A Model for an Intelligent and Adaptive Tutor based on Web by Jackson's Learning Styles Profiler and Expert Systems. arXiv e-prints, arXiv-1304.

O'Mahony, S. M., Sbayeh, A., Horgan, M., O'Flynn, S., \& O'Tuathaigh, C. M. (2016). Association between learning style preferences and anatomy assessment outcomes in graduate- entry and undergraduate medical students. Anatomical sciences education, 9(4), 391-399.

Ozdemir, A., Alaybeyoglu, A., Mulayim, N., \& Balbal, K. F. (2016). Performance evaluation of learning styles based on fuzzy logic inference system. Computer Applications in Engineering Education, 24(6), 853865.

Pane, Apriada. (2017). Belajar Dan Pembelajaran Aprida Pane Muhammad Darwis Dasopang. Fitrah, 03(2), $333-52$

Rais, M., Aryani, F., \& Ahmar, A. S. (2018). The influence of the inquiry learning model and learning style on the drawing technique of students. Glob. J. Eng. Educ, 20(1), 64-68.

Safaan, D., \& Abdelwahab, S. (2021). A Web Based Framework for Learning Styles Identification by Expert System. Journal of Research in Curriculum Instruction and Educational Technology, 7(2), 173-208.

Sari, Ariesta Kartika. (2014). Analisis Karakteristik Gaya Belajar Vak(Visual, Auditorial, Kinestetik)Mahasiswa Pendidikan Informatika Angkatan 2014. Edutic - Scientific Journal of Informatics Education, 1(1), 1-12.

Sari, N. A. (2013). Sistem Pakar Mendiagnosa Penyakit Demam Berdarah Menggunakan Metode Certainty Factor. Pelita Inform. Budi Darma, 4, 100-103.

Shamsuddin, N., \& Kaur, J. (2020). Students' Learning Style and Its Effect on Blended Learning, Does It Matter?. International Journal of Evaluation and Research in Education, 9(1), 195-202.

Sidharta, Iwan, and Mirna Wati. (2015). Perancangan Dan Implementasi Sistem Informasi Urunan Desa (URDES) Berdasarkan Pada Pajak Bumi Dan Bangunan. Jurnal Computech \& Bisnis, 9(2):95-107. 
Soetanto, D., \& MacDonald, M. (2017). Group work and the change of obstacles over time: The influence of learning style and group composition. Active Learning in Higher Education, 18(2), 99-113.

Stirling, B. V., \& Alquraini, W. A. (2017). Using VARK to assess Saudi nursing students' learning style preferences: Do they differ from other health professionals?. Journal of Taibah University Medical Sciences, 12(2), 125-130.

Tasrif, E. (2019). Academic Supervision Mechanism by Vocational High School Supervisor. In 5th UPI International Conference on Technical and Vocational Education and Training (ICTVET 2018) (pp. 160-164). Atlantis Press.

Tasrif, E., Kurnia, H., Pahtoni, T. Y., Kurniadi, D., \& Hadi, A. (2020). Analysis of Development Needs of Foster Parents Communication Media in Supporting Improvement of Academic Achievement of Students with Weak Socio-Economic Background. In The 1st Progress in Science and Technology Research Symposium. Redwhite Press.

Tasrif, E., Saputra, H. K., Kurniadi, D., Hidayat, H., \& Mubai, A. (2021). Designing Website-Based Scholarship Management Application for Teaching of Analytical Hierarchy Process (AHP) in Decision Support Systems (DSS) Subjects. International Journal of Interactive Mobile Technologies, 16(9), 179-191.

Toyama, M., \& Yamazaki, Y. (2020). Are there effects of a match between learning style and teaching style in an EFL classroom?. Innovation in Language Learning and Teaching, 14(3), 243-258.

Untoro, B. (2016). The Effect of Group Investigation and Learning Style on Students' Writing of Analytical Exposition. IJEE (Indonesian Journal of English Education), 3(1), 29-45.

Vorhaus, J. (2010). Learning Styles in Vocational Education and Training. International Encyclopedia of Education, 376-82. doi: 10.1016/B978-0-08-044894-7.00785-5.

Waliyansyah, Rahmat Robi, Mega Novita, and Laelia Puti Aditasar. (2020). Sistem Pakar Penentuan Gaya Belajar Siswa Dengan Metode Forward Chaining Berbasis Web. IT Journal Research and Development, 5(1):32-44. doi: 10.25299/itjrd.2020.vol5(1).4740.

Weng, F., Ho, H. J., Yang, R. J., \& Weng, C. H. (2018). The influence of learning style on learning attitude with multimedia teaching materials. Eurasia journal of mathematics, science and technology education, 15(1), em1659.

Zulfiani, Z., Suwarna, I. P., \& Sumantri, M. F. (2020). Science Adaptive Assessment Tool: Kolb's Learning Style Profile and Student's Higher Order Thinking Skill Level. Jurnal Pendidikan IPA Indonesia, 9(2), 194-207. 